\title{
The aromatase inhibitor letrozole increases epiphyseal growth plate height and tibial length in peripubertal male mice
}

\author{
R Eshet, G Maor ${ }^{1}$, T Ben Ari, M Ben Eliezer, G Gat-Yablonski \\ and $\mathbf{M}$ Phillip
}

Felsenstein Medical Research Center and Institute of Endocrinology and Diabetes, Schneider Children's Medical Center of Israel, Petah Tikva, Sackler School of Medicine, Tel Aviv University, Tel Aviv, Israel

${ }^{1}$ Department of Anatomy and Cell Biology, Rappaport Faculty of Medicine, Technion-Israel Institute of Technology, Haifa, Israel

(Requests for offprints should be addressed to M Phillip, Institute for Endocrinology and Diabetes, National Center for Childhood Diabetes, Schneider Children's Medical Center of Israel, 14 Kaplan St, Petah Tikva 49202, Israel; Email: mosheph@post.tau.ac.il)

\begin{abstract}
Sex hormones may influence longitudinal growth, either indirectly, by affecting the growth-hormone-insulin-like growth factor I (IGF-I) axis, or directly, by affecting changes within the epiphyseal growth plate (EGP). The aim of the present study was to investigate the effects of letrozole, an aromatase inhibitor, on longitudinal growth and changes in the EGP in vivo. Eighteen peripubertal male mice were divided into three groups. The first group was killed at baseline, the second was injected with letrozole (Femara) s.c., $2 \mathrm{mg} / \mathrm{kg}$ body weight/day, for 10 days, and the third was injected with the vehicle alone. Serum testosterone levels were found to be significantly higher in the treated group than in the controls. Letrozole induced a significant increase in body weight, tail length and serum growth hormone level, but had no significant
\end{abstract}

effect on the level of serum IGF-I. On histomorphometric study, there was a significant increase (12\%) in EGP height in the treated animals compared with controls. Immunohistochemistry showed a 3-4-fold letrozole-induced increase in the proliferation of the EGP chondrocytes, as estimated by the number of proliferation cell nuclear antigen-stained cells, and a decrease in the differentiation of the EGP chondrocytes, as estimated by type X collagen staining. Letrozole did not interfere with type II collagen levels. The study group also showed a twofold increase in the number of IGF-I receptor-positive cells compared with controls. In conclusion, the aromatase inhibitor, letrozole, appears to increase the linear growth potential of the EGP in mice.

Journal of Endocrinology (2004) 182, 165-172

\section{Introduction}

Puberty in humans (and sexual maturation in animals) is the period in extrauterine life which is associated with an increase in growth rate (Prader 1989). Serum levels of the sex steroids, growth hormone $(\mathrm{GH})$, and insulin-like growth factor I (IGF-I) are known to increase during puberty, but the interaction between the gonadal steroids and the GH-IGF-I axis has not been elucidated. Both experimental and clinical evidence indicates that the increased steroid secretion at puberty has an indirect effect on the skeletal tissues and that this effect is GH-dependent (Franz \& Rabkin 1965). Estrogen stimulates the release of GH from the pituitary, thereby increasing serum IGF-I levels. Testosterone also stimulates $\mathrm{GH}$ release in the pituitary via its local aromatization to estrogen (Parker et al. 1984). However, the sex steroids may also exert a direct $\mathrm{GH}$-independent effect on skeletal growth. This is supported by the observation that estrogen influences growth in GH-deficient and hypophysectomized rats (Jansson et al. 1983, Gebers et al. 1995). Furthermore, cartilage studies have demonstrated a dose-dependent stimulatory effect of dihydrotestosterone and estradiol on $\left[{ }^{35} \mathrm{~S}\right]$ incorporation into proteoglycans synthesized by rabbit (Takahashi et al. 1984, Corvol et al. 1987) as well as human (Takahashi et al. 1984) chondrocytes in primary cultures. Rabbit and human (Blanchard et al. 1991, Oz et al. 2001) cartilage tissues also convert testosterone to dihydrotestosterone and, to a lesser extent, to estradiol. Thus, cartilage tissue apparently expresses both $5 \alpha$ reductase and aromatase activities during skeletal growth. Indeed, studies have shown that the aromatase P450 mediates the conversion of the androgens, androstenedione and testosterone, into the estrogens, estrone and $17 \beta$-estradiol. In addition, researchers have demonstrated the expression and activity of androgen- and estrogen-synthesizing enzymes in osteoblast-like cells, suggesting that local metabolism of sex steroids may contribute to bone mass accrual and bone remodeling (Saito \& Yanaihara 1998).

In mammals, longitudinal growth occurs at the growth plate. However, the role played by the locally produced estrogen and androgens within the epiphyseal growth plate 
(EGP) remains unclear. A direct regulatory role of androgens and estrogens has been suggested by the presence of the androgen receptor (AR) (Colvard et al. 1989, Van der Eerden et al. 2002b) and both estrogen receptors, ER $\alpha$ and $\mathrm{ER} \beta$, in growth plate tissue at the mRNA and protein level in several species, including rats, rabbits and humans (Kusek et al. 1998, Kennedy et al. 1999, Nilsson et al. 1999, Braidman et al. 2001, Van der Eerden et al. 2002a,b, Batra et al. 2003). There are also two reported cases of impaired local estrogen activity due to an estrogen receptor deficiency (Smith et al. 1994) or an aromatase deficiency (Morishima et al. 1995) in association with delayed skeletal growth. Both men had an unfused epiphyses and osteopenia. Interestingly, however, neither had a documented pubertal growth spurt, but instead attained extraordinary stature by continuing to grow long after normal males have undergone epiphyses fusion.

The growth plate in mammals consists of three zones: resting, proliferative and hypertropic. The resting zone lies adjacent to the epiphyseal bone and infrequently contains dividing chondrocytes. The proliferative zone contains replicating chondrocytes arranged in columns parallel to the long axis of the bone. The proliferative chondrocytes located farthest from the resting zone stop replicating and enlarge to become hypertropic chondrocytes (Schenk \& Hunziker 1991). These terminally differentiated cells maintain a columnar alignment in the hypertropic zone. The simultaneous processes of chondrocyte proliferation, hypertropy and cartilage matrix secretion result in chondrogenesis. Simultaneously, the metaphyseal border of the growth plate is invaded by blood vessels and bone cell precursors that remodel the newly formed cartilage into bone (Schenk \& Hunziker 1991). The synchronized processes of chondrogenesis and cartilage ossification lead to longitudinal bone growth. At the onset of sexual maturation, the growth plate undergoes structural and functional changes. There is a gradual decline in the overall growth plate height (Masoud et al. 1986), proliferative zone height (Walker \& Kember 1972), hypertropic zone height (Kember \& Walker 1971), size of hypertropic chondrocytes (Kember \& Walker 1971, Hunziker \& Schenk 1989, Breur et al. 1991), and column density (Kember 1971).

Unlike in humans, the growth plates in mice do not fuse completely during sexual maturation (Roach et al. 2003). However, their height diminishes considerably after sexual maturation, and the protein synthesis rate in the chondrocytes decreases. Thus, in mice, as in humans, sex steroids may play a crucial role in the regulation of cartilage growth (Vidal et al. 1999).

$\mathrm{Oz}$ et al. (2000) observed a sexual dimorphic response in bone using an aromatase-deficient mouse model (ArKO) created by the targeted disruption of cyp 19, the aromatase gene. Both sexes showed osteopenia in the lumbar spine and an osteoporotic phenotype. However, in males aromatase deficiency contributed to a clear suppression of bone formation, and femur length was shorter than in the wild-type littermates. These findings were supported by studies in estrogen-receptor knockout models in which male ER $\alpha$ (ERKO) and ER-double knockout mice (DERKO), but not ER $\beta$ (BERKO) mice, displayed decreased longitudinal and radial skeletal growth with pronounced cortical osteopenia. It is presently unknown to what extent the conversion of androgens into estrogens is important for skeletal growth in males. Aromatase inhibition of this conversion may, at least partly, explain the effect of androgens or, alternatively, the effect of the lack of estrogen on longitudinal growth.

The aim of the present study was to investigate the effect of aromatase inhibition on tibial longitudinal growth and on the changes within the growth plate in peripubertal male mice. We initiated treatment at the expected age of prepuberty, before the onset of sexual maturation, in order to mimic physiological conditions. For the purposes of the study, we used letrozole (Femara), an active, nonsteroidal, nitrogen-containing compound which selectively inhibits cytochrome P450 aromatase by binding its heme iron. Letrozole has no estrogenic, anti-estrogenic or antiandrogenic properties at doses required to inhibit estrogen synthesis (Gershanovich et al. 1998). It is therefore useful for the study of the cellular mechanisms in the mice growth plate and for comparison of the action of testosterone and estrogen. Recently, Wickman et al. (2001) observed a potential increase in adult height in boys with delayed puberty who were treated with letrozole, providing a rationale for the study of means to delay bone maturation in several growth disorders.

\section{Materials and Methods}

Three-week-old male Institute of Cancer Research (ICR) mice were purchased from Harlan (Jerusalem, Israel). Animal breeding complied with the National Institutes of Health Guide for the Care and Use of Laboratory Animals and was authorized by the Committee for the Ethical Care and Use of Laboratory Animals of Tel Aviv University. Animals were housed in standard laboratory cages and were fed normal mouse chow which was available ad libitum; there was free access to unlimited supplies of tap water.

The mice were divided into three groups of six animals each. The first group was killed at baseline. The second group was treated for 10 days with letrozole (Femara; kindly provided by Novartis Pharma AG, Switzerland) at a dose of $2 \mathrm{mg} / \mathrm{kg}$ body weight/day in $0 \cdot 3 \%$ hydroxypropylcellulose (HPC), administered subcutaneously (study group). The third group was injected with vehicle alone ( $0 \cdot 3 \% \mathrm{HPC}, 0 \cdot 1 \mathrm{ml} / \mathrm{mouse} /$ day) for the same period (control group). Animals were weighed at the beginning of the study and before death, 10 days after the first injection, by inhalation of $\mathrm{CO}_{2}$. Thereafter, trunk 
blood was collected, and serum was separated and kept at $-20{ }^{\circ} \mathrm{C}$ for later measurements of GH, IGF-I, and testosterone levels. Two tibias from each mouse were carefully removed, measured and processed for histomorphologic assessment and immunohistochemistry studies, as described in the respective sections.

\section{Blood hormone analysis}

Serum IGF-I was measured by the functional separation method as previously described by us (Phillip et al. 2001). Acidic extraction was used to detach IGF-I from its binding proteins; therefore, the results represent the total IGF-I level. Serum testosterone was measured with the TESTO-CT2 kit (CIS Biointernational, Gif-sur-Yvette Cedex, France). The sensitivity of the assay is approximately $0 \cdot 1 \mathrm{nmol} / 1$. Serum GH was measured by a modified radioimmunoassay as previously described (Phillip et al. 2001).

\section{Morphology}

Tibias were fixed in 10\% buffered formalin solution, $\mathrm{pH}$ $7 \cdot 2$, for $48 \mathrm{~h}$. Bones were then decalcified in 20\% TrisEDTA buffer, $\mathrm{pH} 7 \cdot 2$, for 10 days, dehydrated in gradually increasing concentrations of ethanol, and embedded in paraffin blocks. Paraffin sections $(5 \mu \mathrm{m})$ were deparaffinized in xylene, hydrated in graduated ethanols, and pretreated with $3 \%$ acetic acid for $3 \mathrm{~min}$. The sections were then stained with $1 \%$ Alcian blue at $\mathrm{pH} 2.5$ for 30 min, thoroughly rinsed with tap water, and counterstained with hematoxylin and eosin for morphometric studies. The length of the various cellular layers in the cartilaginous zone of the tibial growth plate was determined with an Olympus DP-Soft imaging system program using appropriate morphometry software (Olympus, Lake Success, NY, USA). The system consists of an Olympus BX41 system photomicroscope $(\times 10$ objective $)$ fitted with an Olympus DP 11 camera attached to a personal computer. The height of the EGP from the apical border of the reserve zone cell layer to the lower border of the mineralized cartilage was measured. The results shown are the average of 11 measurements taken from various zones of the EGP in each section, performed on two sections from each tibia, and from the two tibias in each mouse.

\section{Immunohistochemistry}

Deparaffinized sections were incubated for $25 \mathrm{~min}$ in 3\% $\mathrm{H}_{2} \mathrm{O}_{2}$ in methanol to inactivate endogenous peroxidases, blocked with $10 \%$ non-immune serum compatible with the second antibody, and incubated with a specific antibody for $2 \mathrm{~h}$ at room temperature: rabbit anti-aromatase (cat. no. 0719-1009; Biogenesis, Kingston, NH, USA), rabbit anti-IGF-I receptor (anti-IGF-IR) (anti- $\alpha$-subunit, cat. no. SC-712; Biotechnology Inc., Santa Cruz, CA,
USA), mouse anti-collagen type X (cat. no. MS-852PO; Neomarkers, Fremont, CA, USA), mouse anti-collagen type II (cat. no. MAB 8887; Chemicon International, Temecula, CA, USA), or mouse anti-proliferating cell nuclear antigen (anti-PCNA) (cat. no. 08-0110; Zymed Laboratories Inc., San Francisco, CA, USA). Positive binding was visualized with the appropriate biotinylated second antibody and streptavidin-peroxidase conjugated with aminoethyl carbazole (AEC) as a substrate (Histostatin-SP kit, Zymed Lab Inc.). Counterstaining was carried out with hematoxylin. To detect type II and type X collagen, an additional step of protein digestion was necessary. For type II, the slides were incubated with $1 \mathrm{mg} / \mathrm{ml}$ pepsin in Tris- $\mathrm{HCl}, \mathrm{pH} 2 \cdot 0$, for $10 \mathrm{~min}$ at $37^{\circ} \mathrm{C}$. For type X, $5 \mathrm{~min}$ microwave boiling in retrieval buffer $(2 \mathrm{mM}$ citric acid, $8 \mathrm{mM}$ sodium citrate; $\mathrm{pH} 6.0$ ) was required before pepsin treatment.

Negative controls were incubated with a non-immune serum of the same species in which the first antibody was raised.

\section{Statistics}

Morphometric findings were analyzed with analysis of variance (ANOVA) with repeated measures. Betweengroup differences for the other data were analyzed with Student's $t$-test. A $P$ value of $<0.05$ was considered significant. Values are given as means \pm S.E.M.

\section{Results}

Table 1 shows the effect of letrozole on the growth parameters and the hormone profile. There was no significant difference in body weight among the 3 groups of animals at baseline. After 10 days of treatment with letrozole, the study mice showed a $14 \%$ increase in weight compared with controls $(P<0 \cdot 05)$. They also had a significant increase in tail length $(P<0.05)$ and tibia length $(P<0 \cdot 05)$.

During the 10-day experiment, the level of testosterone in the control group gradually rose as the mice approached sexual maturation. However, after 10 days of treatment, the level of serum testosterone in the letrozole-treated group was significantly higher than in the controls $(P<0 \cdot 00001)$. The study mice also showed a significant increase in serum GH compared with the controls $(P<0 \cdot 05)$, but there was no significant change in serum IGF-I levels.

Figure 1 shows the immunostaining results in the excised tibial EGP. The aromatase was detected mostly in the hypertropic and prehypertropic cells, with only slight staining in the proliferative and resting zones. No staining was observed in the negative controls incubated with nonimmune rabbit serum (data not shown). 
Table 1 Effects of letrozole on growth parameters and systemic hormonal profile (testosterone, $\mathrm{GH}$ and IGF-I). Data are reported as means \pm S.E.M.

\begin{tabular}{|c|c|c|c|c|}
\hline & $\begin{array}{l}\text { Base* }^{*} \\
(n=6)\end{array}$ & $\begin{array}{l}\text { Control } \\
\text { (vehicle only) } \\
(n=6)\end{array}$ & $\begin{array}{l}\text { Letrozole-treated } \\
(n=6)\end{array}$ & $P^{* *}$ \\
\hline \multicolumn{5}{|l|}{ Parameter } \\
\hline Baseline weight (g) & $15 \cdot 60 \pm 0 \cdot 73$ & $15 \cdot 16 \pm 1 \cdot 08$ & $16 \cdot 23 \pm 0 \cdot 72$ & NS \\
\hline Final weight (g) & & $24 \cdot 4 \pm 1 \cdot 77$ & $31 \cdot 2 \pm 1 \cdot 02$ & $<0.05$ \\
\hline Tail length (cm) & $6 \cdot 74 \pm 0 \cdot 35$ & $8 \cdot 11 \pm 0 \cdot 12$ & $8 \cdot 38 \pm 0 \cdot 08$ & $<0.05$ \\
\hline Tibia length $(\mathrm{cm})$ & $1 \cdot 68 \pm 0.01$ & $1 \cdot 87 \pm 0 \cdot 03$ & $1.95 \pm 0.02$ & $<0.05$ \\
\hline Testosterone (nmol/l) & $1 \cdot 55 \pm 1 \cdot 2$ & $12 \cdot 93 \pm 5 \cdot 45$ & $84 \cdot 16 \pm 5 \cdot 78$ & $<0.00001$ \\
\hline $\mathrm{GH}(\mathrm{ng} / \mathrm{ml})$ & $11 \cdot 3 \pm 2 \cdot 2$ & $14 \cdot 18 \pm 2 \cdot 88$ & $115 \cdot 5 \pm 88 \cdot 76$ & $<0.05$ \\
\hline IGF-I (ng/ml) & $623 \cdot 00 \pm 30 \cdot 12$ & $822 \cdot 66 \pm 56 \cdot 00$ & $842 \cdot 21 \pm 56 \cdot 00$ & NS \\
\hline
\end{tabular}

*Killed at baseline

${ }^{* *}$ Significance of difference between letrozole-treated group and control group; NS, not significant.

As seen in Fig. 1, the treated group (B) had a 3·4-fold greater increase in the number of PCNA-positive cells in the EGP than controls (C) $(119 \cdot 12 \pm 81 \cdot 17$ vs $34 \cdot 64 \pm$ $28 \cdot 15$ stained nuclei $\left./ \mathrm{mm}^{2}, P<0 \cdot 02\right)$. Furthermore, only cells in the proliferative zone were positively stained with anti-PCNA antibodies.

Immunohistochemical localization of the IGF-I receptor in the EGP showed an increment in IGF-I receptor abundance in the prehypertropic and hypertropic zones of the chondrocytes in the EGP of the letrozole-treated mice. Ten days of treatment induced a twofold increase in the number of cells positive for IGF-I receptors per growth plate in the study group compared with controls $(11 \cdot 4 \pm$ $5 \cdot 5$ vs $5 \cdot 6 \pm 2 \cdot 6, P<0 \cdot 05$ ) (Fig. $1 \mathrm{D}, \mathrm{E}$ ).

After 10 days of treatment, the study group showed a $12 \%$ greater increase in EGP height than the controls

Figure 1 (A) Aromatase distribution within male mouse EGP. Immunohistochemical detection of aromatase in sections derived from a 3-week-old ICR male mouse. Slides incubated with nonimmune rabbit serum served as negative controls and no staining was detected (data not shown). The aromatase was distributed mostly in the hypertropic and pre-hypertropic cells (lower arrow) and slightly in the proliferative and resting zone (upper and middle arrows respectively). (B and C) Effect of letrozole on EGP cell proliferation. Proliferation activity was determined by measuring levels of PCNA immunohistochemically. Positive cell nuclei stained red, and were detected in the proliferative zone. Two independent immunostainings were performed in every two slides from the tibia of every mouse. On each slide, there were three sections. Three observers counted the number of positive cells in a double-blind manner in all the sections. There was a $3 \cdot 4$-fold increase in the number of PCNA-stained granules $/ \mathrm{mm}^{2}$ in the letrozole-treated cells (B) compared with controls $(C)(P<0.05) ; n=6$ in each group. (D and E) Effect of letrozole on IGF-I receptors in the EGP. Immunohistochemical detection of IGF-I receptor in the treated group (D) compared with the controls (E) shows a twofold increase in the number of IGF-I receptor-positive cells per growth plate upon treatment $(P<0 \cdot 05)$ (arrows show positive staining cells in the pre-hypertropic and hypertropic zones); $n=6$ in each group.
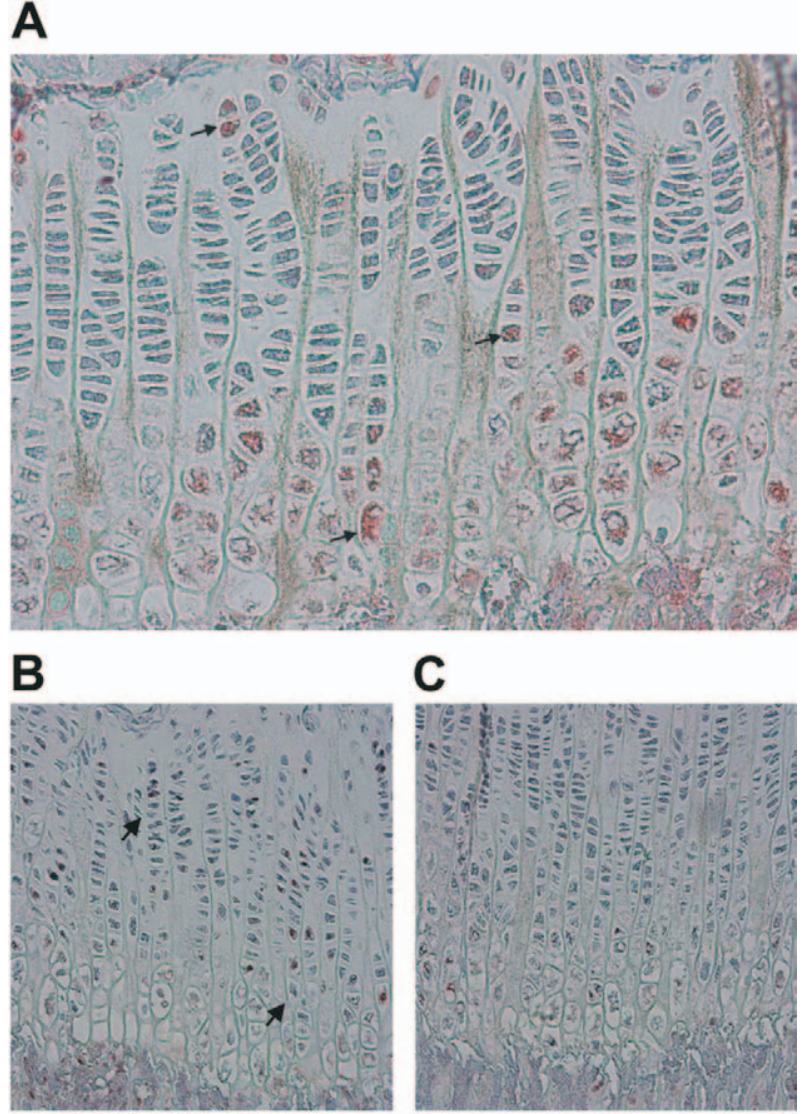

D

E

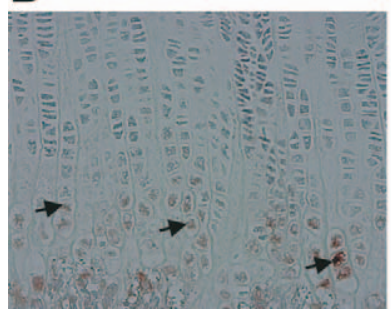

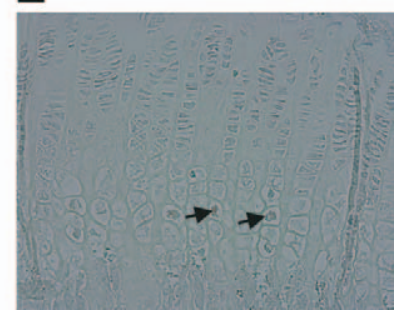



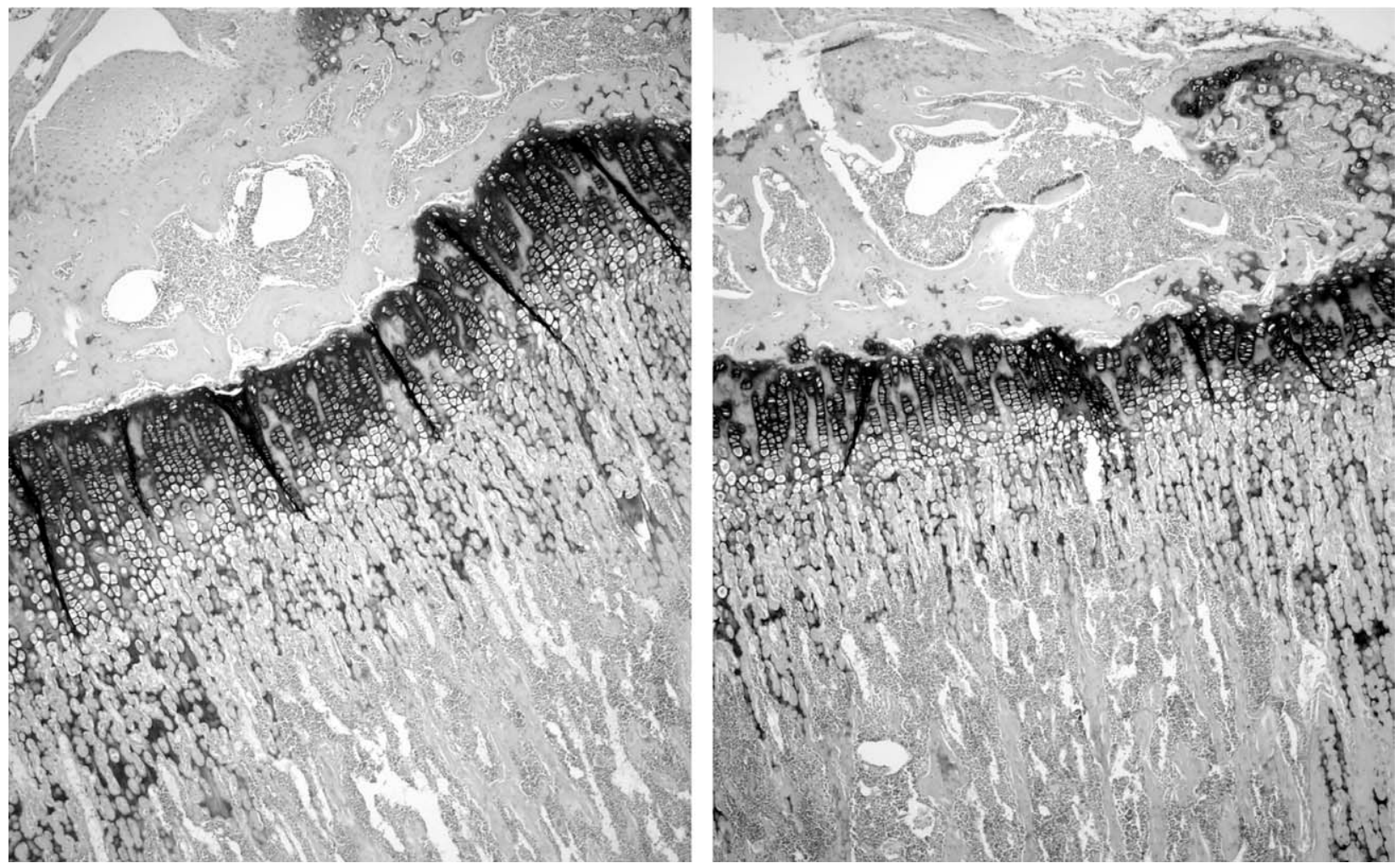

Figure 2 Effect of letrozole on tibial EGP height. Morphometric analysis of the EGP height was performed on hematoxylin and eosin-stained sections. The EGP height in the whole section increased by $12 \%$ in the letrozole-treated mice (left) compared with controls (right) $(P<0 \cdot 05)$. ANOVA values are mean \pm S.E.M.; $n=6$ in each group.

$(292 \cdot 16 \pm 26 \cdot 44 \mu \mathrm{m} \quad$ vs $260 \cdot 83 \pm 13 \cdot 56 \mu \mathrm{m}, \quad P<0 \cdot 05)$ (Fig. 2 ). The ratio of the proliferating to hypertropic cells was not significantly different between the control and the treated group.

Letrozole did not affect the level of type II collagen, a major component of the cartilaginous matrix and one of the early parameters of proper chondrogenesis. The abundance of type II collagen was similar in the letrozoletreated and control groups (data not shown). By contrast, letrozole had a clear inhibitory effect on type X collagen abundance in the mature hypertropic chondrocytes (Fig. 3).

\section{Discussion}

The GH-independent stimulatory effects of androgens on growth have been demonstrated in humans (Attie et al. 1990) and in animal models (Phillip et al. 1992). In men, estrogen deficiency caused by a mutation either in the estrogen receptor gene (Smith et al. 1994) or in the P450 aromatase gene (Morishima et al. 1995, Carani et al. 1997) led to impaired skeletal maturation, continued growth into adult life, and very tall stature. In women with aromatase deficiency, androgen levels were excessive, causing inappropriate virilization but failing to induce skeletal maturity. These findings indicate that androgen alone, even at supraphysiological levels, does not affect epiphyseal fusion. Rather, it is estrogen that, by enhancing osteogenesis at the expense of chondrogenesis, accelerates the epiphyseal fusion rate and terminates linear growth (Cutler 1997). Furthermore, in a study in rabbits, Weise et al. (2001) suggested that epiphyseal fusion is triggered when the proliferative potential of growth plate chondrocytes is exhausted, and that estrogen accelerates the programmed senescence of the growth plate, thereby causing earlier epiphyseal fusion.

Endochondral bone formation in mice differs from that in humans, as their growth plates do not fuse completely during sexual maturation (Roach et al. 2003). Therefore, it can be argued that estrogen receptors in mice, unlike those in humans, do not mediate growth plate fusion (Lubahn et al. 1993). However, after sexual maturation, the height of the mouse growth plate diminishes considerably and the protein synthesis rate in the chondrocytes decreases, indicating that in mice also, sex steroids may play a crucial role in regulating cartilage growth (Vidal et al. 1999).

Prompted by studies indicating a direct regulatory role of androgens and estrogens in the growth plate (Lubahn et al. 1993, Kusek et al. 1998, Kennedy et al. 1999, Nilsson et al. 1999, Braidman et al. 2001, Van der Eerden et al. 

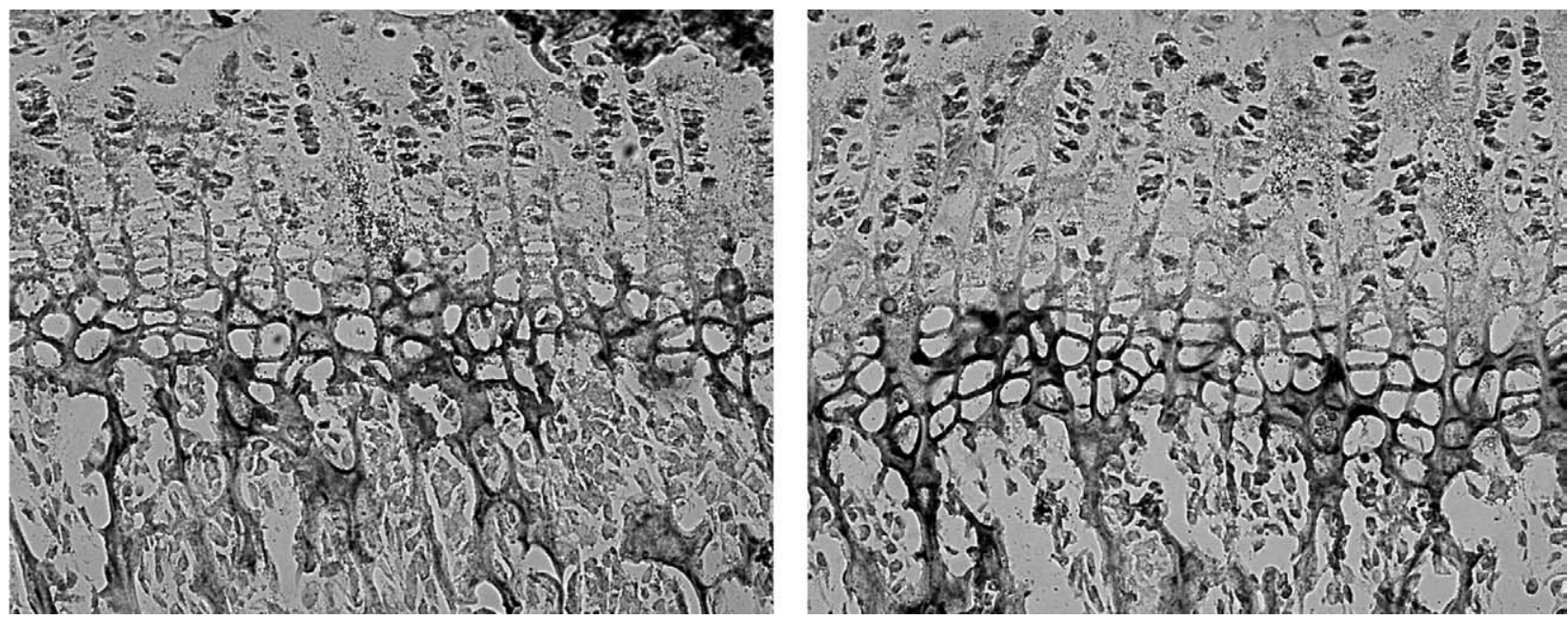

Figure 3 Effect of letrozole on type X collagen levels. Immunohistochemical detection of collagen type X in the tibial EGP. Letrozole decreased the positive red staining within the matrix of the mature hypertropic cells in the letrozole-treated group (left) compared with controls (right). Two independent immunostainings were performed in every two slides from the tibia of every mouse. On each slide, $2-3$ sections were observed.

2002a, Batra et al. 2003), we investigated the effect of the highly selective nonsteroidal aromatase inhibitor, letrozole, on growth in peripubertal male mice. To prove that letrozole inhibits aromatase activity, we first examined its effect on granulosa cells from ovaries of female mice. Using the water assay technique (Reed \& Ohno 1976), we noted a $96 \%$ inhibition of aromatase activity (data not shown).

The results of the present work show that aromatase is present in the EGP, mostly in the hypertropic and prehypertropic cells, and slightly in the proliferative and resting zones. The inhibition of aromatase activity by letrozole in vivo was followed by a significant increase in body weight and tail and tibial length, in addition to a significant increase in EGP height. Nevertheless, the ratio of proliferating to hypertropic cells was not significantly different between the control and treated group, indicating that the effect on the EGP was balanced. Together, these findings suggest that the aromatization of androgen into estrogen is involved in the regulation of cartilage growth in mice.

Our findings are different from earlier studies in both aromatase receptor knockout male mice (ArKO) (Murata et al. 2002) and estrogen receptor knockout male mice (ERKO, DERKO) (Vidal et al. 2000), which reported a decrease in longitudinal and radial skeletal growth. This discrepancy may be explained by the fact that the depletion of estrogens in the ArKO male mice and the lack of estrogen receptors in the ERKO and DERKO male mice were inborn, whereas the male mice in our study were exposed to a short-term (10 days) lack of estrogens and increasing levels of androgens at the prepubertal stage only. Our results also disagree with those of Vanderschueren et al. (1996, 1997), who found that aromatase inhibition reduced body weight gain, and skeletal size and modeling. However, they used a different specific inhibitor (vorozole) and an oral route of administration. More importantly, their rats were either 60 days old (postpubertal) already at the beginning of the experiment and were killed after 18 weeks of treatment (adult), or 12 months old (mature adult) at the beginning of the experiment and treated for 4 months. By contrast, all our mice were 21 days old (peripubertal) and were killed after 10 days of treatment.

In an earlier study, our group found that the administration of testosterone to hypophysectomized/castrated rats increased the EGP height and the abundance of IGF-I receptors in the EGP, without affecting serum IGF-I levels (Phillip et al. 1992). This finding was replicated in the present study and is in line with the lack of effect of the aromatase inhibitor letrozole on serum IGF-I levels. However, aromatase inhibition increased serum GH levels and the abundance of IGF-I receptor in the tibial EGP. As observed by Takigawa et al. (1997), the expression of IGF-I receptor reflects the sensitivity of tissue cells to IGF-I activity. Therefore, the increment in IGF-I receptor indicates that the IGF system might be involved, at least partially, in mediating the effects of the aromatase inhibitor on the EGP. In the present study, the animals were intact, so the effect of letrozole on serum GH may be explained by the effect of gonadal steroids on the GH secretory pattern. It was previously reported that testosterone may act through an androgen receptor-dependent pathway or it may undergo aromatization to $17 \beta$-estradiol and then exert its action on the $\mathrm{GH}$ axis via estrogen receptors. In humans, androgens affect $\mathrm{GH}$ production mostly through 
aromatization to estrogens (Weissberger \& Ho 1993). In rodents, however, both aromatizable and nonaromatizable androgens affect GH release (Argente et al. 1990, Gevers et al. 1998). Our findings demonstrate that in the presence of the aromatase inhibitor, testosterone increases serum $\mathrm{GH}$ levels in mice, apparently through activation of androgen receptors.

Normal skeletal growth depends on the coupling of proliferation, differentiation and maturation activities within the skeletal growth centers. In our study, letrozole significantly increased the proliferative activity of the EGP cells, as indicated by the increment in PCNA staining, and apparently decreased chondrocyte differentiation and maturation, as demonstrated by the decrement in the level of type X collagen, a highly specific marker of hypertropic chondrocyte terminal differentiation. However, chondrogenesis, as expressed by collagen type II levels, was not affected. These results suggest that estrogen is probably involved in the decreased proliferation and enhanced maturation activities of the EGP chondrocytes, which may affect the rate of longitudinal growth. Indeed, we recently found that estrogen accelerates osteogenesis and increases the apoptosis rate in male-derived skeletal growth centers (G Maor, unpublished data).

In a previous study performed on an in vitro model of mandibular condyle, we showed that testosterone directly stimulates the expression of IGF-I receptor and its abundance in the chondrocytes of the bone growth centers. We also demonstrated that testosterone stimulates chondrocyte proliferation independently of the presence of GH (Maor et al. 1999). It is therefore reasonable to assume that the effect of letrozole both on IGF-I receptor abundance and on chondrocyte proliferation is due to the effect of both systemic and local testosterone levels, while the effect of letrozole on the inhibition of differentiation is mediated through the reduction of estrogen levels.

In summary, the aromatase inhibitor, letrozole, increased the length of the tibia and tail and the height of the EGP in mice. In vivo, letrozole influences the balance between testosterone and estrogen and induces a combined effect. By inhibiting the conversion of testosterone to estrogen, it affects GH secretion. In addition, it acts directly on skeletal growth by affecting the local balance between testosterone and estrogen at the EGP. As postulated in a previous study, testosterone apparently has a GH-independent stimulatory effect on skeletal growth that is exerted directly on the EGP. This effect is probably mediated by increased responsiveness to endocrine and paracrine IGF-I, as reflected by the increase in IGF-I receptor levels in the EGP. In addition, by decreasing estrogen levels, letrozole attenuates the final differentiation of the hypertropic cells.

The extrapolation of our findings on letrozole-induced growth enhancement from mice to humans and the elucidation of the exact mechanism underlying the effect of the aromatase inhibitor on the EGP require further investigations. Our findings may have implications for the therapeutic delay of bone maturation in several growth disorders.

\section{Acknowledgement}

We thank Mrs Pnina Lilos for her assistance in the statistical analysis. There is no conflict of interest that would prejudice the impartiality of this study. We are grateful to Novartis Pharma AG, Switzerland, for their contribution of the letrozole.

\section{References}

Argente J, Chowen-Breed JA, Steiner RA \& Clifton DK 1990 Somatostatin messenger RNA in hypothalamic neurons is increased by testosterone through activation of androgen receptors and not by aromatisation to estradiol. Neuroendocrinology 52 342-349.

Attie KM, Ramirez NR, Conte FA, Kaplan SL \& Grumbach MM 1990 The pubertal growth spurt in eight patients with true precocious puberty and growth hormone deficiency: evidence for a direct role of sex steroids. Journal of Clinical Endocrinology and Metabolism 71 975-998.

Batra GS, Hainey L, Freemont AJ, Andrew G, Sauders PTK, Hoyland JA \& Braidman IP 2003 Evidence for cell-specific changes with age in expression of oestrogen receptor (ER) $\alpha$ and $\beta$ in bone fractures from men and women. Journal of Pathology 200 65-73.

Blanchard O, Tsagris L, Rappaport R, Duval-Beaupere G \& Corvol MT 1991 Age-dependent responsiveness of rabbit and human cartilage cells to sex steroids in vitro. Journal of Steroid Biochemistry and Molecular Biology 40 711-716.

Braidman IP, Hainey L, Batra G, Selby PL, Saunders PTK \& Hoyland J 2001 Localization of estrogen receptor $\beta$ protein expression in the adult human bone. Journal of Bone and Mineral Research 16 214-220.

Breur GJ, Van Enkevort BA, Farnum CE \& Wilsman NJ 1991 Linear relationship between the volume of hypertrophic chondrocytes and the rate of longitudinal bone growth in growth plates. Journal of Orthopedic Research 9 348-359.

Carani C, Qin K, Simoni M, Faustini Fustini M, Serpente S, Boyd J, Korach KS \& Simpson ER 1997 Effect of testosterone and estradiol in a man with aromatase deficiency. New England Journal of Medicine 337 91-95.

Colvard DS, Eriksen EF, Keeting PE, Wilson EM, Lubahn French FS, Riggs BL \& Spelsberg TC 1989 Identification of androgen receptors in normal human osteoblast-like cells. PNAS 86 854-857.

Corvol MT, Carascosa A, Tsagris L, Blanchard O \& Rappaport R 1987 Evidence for a direct in vitro action of sex steroids on rabbit cartilage cells during skeletal growth: influence of age and sex. Endocrinology 120 1422-1429.

Cutler GB Jr 1997 The role of estrogen in bone growth and maturation during childhood and adolescence. Journal of Steroid Biochemistry and Molecular Biology 61 141-144.

Franz AG \& Rabkin MT 1965 Effects of estrogen and sex difference on secretion of human growth hormone. Journal of Clinical Endocrinology and Metabolism 25 1470-1480.

Gebers EF, Wit JM \& Robinson ICAF 1995 Effect of gonadectomy on growth and GH responsiveness in dwarf rats. Journal of Endocrinology 145 69-79.

Gershanovich M, Chaudri HA, Campos D, Lurie H, Bonaventura A, Jeffrey M, Buzzi F, Bodrogi I \& Lassus M 1998 Letrozole, a new oral aromatase inhibitor: randomized trial comparing $2.5 \mathrm{mg}$ daily, $0.5 \mathrm{mg}$ daily and aminoglutethimide in postmenopausal women with advanced breast cancer. Annals of Oncology 9 639-645. 
Gevers E, Pincus SM, Robinson ICAF \& Veldhuis JD 1998 Differential orderliness of the $\mathrm{GH}$ release process in castrate male and female rats. American Journal of Physiology 274 R437-R444.

Hunziker EB \& Schenk RK 1989 Physiological mechanisms adopted by chondrocytes in regulating longitudinal bone growth in rats. Journal of Physiology 414 55-71.

Jansson JO, Eden S \& Isaksson O 1983 Sites of action of testosterone and estradiol on longitudinal bone growth. American Journal of Physiology 144 E135-E140.

Kember NF 1971 Cell population kinetics of bone growth: the first ten years of autoradiographic studies with tritiated thymidine. Clinical Orthopaedics and Related Research 76 213-230.

Kember NF \& Walker KV 1971 Control of bone growth in rats. Nature 229 428-429.

Kennedy J, Baris C, Hoyland JA, Selby PL, Freemont AJ \& Braidman IP 1999 Immunofluorescent localization of estrogen receptor- $\alpha$ in growth plates of rabbits, but not in rats, at sexual maturity. Bone $\mathbf{2 4}$ $9-16$.

Kusek V, Virdi AS, Prince R \& Triffit JT 1998 Localization of estrogen receptor- $\alpha$ in human and rabbit skeletal tissues. Journal of Clinical Endocrinology and Metabolism 83 2421-2428.

Lubahn DB, Moyer JS, Golding TS, Couse JF, Korash KS \& Smithies O 1993 Alterations of reproductive function but not prenatal sexual development after insertional disruption of the mouse estrogen receptor gene. PNAS 90 11162-11166.

Maor G, Segev Y \& Phillip M 1999 Testosterone stimulates insulin-like growth factor-I and insulin-like growth factor-I-receptor gene expression in the mandibular condyle - a model of endochondral ossification. Endocrinology 140 1901-1910.

Masoud I, Shapiro F \& Moses A 1986 Tibial epiphyseal development: a cross-sectional histologic and histomorphometric study in the New Zealand white rabbit. Journal of Orthopedic Research 4 212-220.

Morishima A, Grumbach MM, Simpson ER, Fisher C \& Qin K 1995 Aromatase deficiency in male and female siblings caused by a novel mutation and the physiological role of estrogens. Journal of Clinical Endocrinology and Metabolism 80 3689-3698.

Murata Y, Robertson KM, Jones MEE \& Simpson ER 2002 Effect of estrogen deficiency in the male: the ArKO mouse model. Molecular and Cellular Endocrinology 193 7-12.

Nilsson LO, Boman A, Savendahl L, Grigelioniene G, Ohlsson C, Ritzen EM \& Wroblewski J 1999 Demonstration of estrogen receptor- $\beta$ immunoreactivity in human growth plate cartilage. Journal of Clinical Endocrinology and Metabolism 84 370-373.

Oz OK, Zerwekh JE, Fisher C, Graves K, Nanu L, Millsaps R \& Simpson ER 2000 Bone has a sexually dimorphic response to aromatase deficiency. Journal of Bone and Mineral Research $\mathbf{1 5}$ $507-514$.

Oz OK, Millsaps R, Welch R, Birch J, Birch J \& Zerwekh JE 2001 Expression of aromatase in the human growth plate. Journal of Molecular Endocrinology 27 249-253.

Parker MW, Johanson AJ, Rogol AD, Kaiser DL \& Blizzard RM 1984 Effect of testosterone on somatomedin C concentrations in prepubertal boys. Journal of Clinical Endocrinology and Metabolism $\mathbf{5 8}$ 87-90.

Phillip M, Palese T, Hernandez ER, Roberts CT, Le Roith JD \& Kowarski AA 1992 Effect of testosterone on insulin-like growth factor I (IGF-I) and IGF-I receptor gene expression in the hypophysectomized rat. Endocrinology 130 2865-2870.

Phillip M, Maor G, Assa S, Silbergeld A \& Segev Y 2001 Testosterone stimulates growth of tibial epiphyseal growth plate and insulin like growth factor I receptor abundance in hypophysectomized and castrated rats. Endocrine 16 1-6.

Prader A 1989 Hormonal regulation of growth and the adolescent growth spurt. In Control of the Onset of Puberty, pp 534-546. Eds MM Grumbach, P Sizonenko \& M Aubet. Baltimore: Williams \& Wilkins.
Reed KC \& Ohno S 1976 Kinetic properties of human placental aromatase. Application of an assay measuring ${ }^{3} \mathrm{H}_{2} \mathrm{O}$ release from 1 beta, 2 beta- ${ }^{3} \mathrm{H}$-androgens. Journal of Biological Chemistry 252 $1625-1631$

Roach HI, Mehta G, Oreffo ROC, Clarke NMP \& Cooper C 2003 Temporal analysis of rat growth plates: cessation of growth with age despite presence of a physis. Journal of Histochemistry and Cytochemistry 51 373-383.

Saito H \& Yanaihara T 1998 Steroid formation in osteoblast-like cells. Journal of Internal Medical Research 26 1-12.

Schenk RK \& Hunziker EB 1991 Rickets. In Nestle Nutrition Workshop Series, pp 63-76. Eds Glorieux FH, New York: Raven.

Smith EP, Boyd J, Frank GR, Takahashi T, Cohen RM, Specker B, Williams TC, Lubahn DB \& Korach KS 1994 Estrogen resistance caused by a mutation in the estrogen-receptor gene in a man. New England Journal of Medicine 331 1056-1061.

Takahashi Y, Corvol MT, Tsagris L, Carascosa A, Bok S \& Rappaport R 1984 Testosterone metabolism in prepubertal rabbit cartilage. Molecular and Cellular Endocrinology 35 15-24.

Takigawa M, Okawa T, Pan H, Aoki, Takahashi K, Zue J, Suzuki F \& Kinoshita A 1997 Insulin-like growth factors I and II are autocrine factors in stimulating proteoglycan synthesis, a marker of differentiated chondrocytes, acting through their respective receptors on a clonal human chondrosarcoma-derived chondrocyte cell line, HCS-2/8. Endocrinology 138 4390-4400.

Van der Eerden BCJ, Gevers EF, Lowik CW, Karperien M \& Wit JM 2002a Expression of estrogen receptor $\alpha$ and $\beta$ in the epiphyseal plate of the rat. Bone 30 478-485.

Van der Eerden BCJ, Van Til NP, Brinkmann AO, Lowik CWGM, Wit JM \& Karperian M $2002 b$ Sex differences in the expression of the androgen receptor in the tibial growth plate and metaphyseal bone of the rat. Bone 30 891-896.

Vanderschueren D, Van Herck E, De Coster R \& Bouillon R 1996 Aromatization of androgens is important for skeletal maintenance of aged male rats. Calcified Tissue International 59 179-183.

Vanderschueren D, Van Herck E, Nijs J, Ederveen GH, De Coster R \& Bouillon R Aromatase inhibition impairs modeling and decreases bone mineral density in growing male rats. Endocrinology 138 2301-2307.

Vidal O, Lindberg M, Savendahl L, Lubahn DB, Ritzen EM, Gustafsson JA \& Ohlsson C 1999 Disproportional body growth in female estrogen receptor- $\alpha$ inactivated mice. Biochemical and Biophysical Research Communications 265 569-571.

Vidal O, Lindberg MK, Hollberg K, Baylink DJ, Andersson G, Lubahn DB, Mohan S, Gustafsson JA \& Ohlsson C 2000 Estrogen receptor specificity in the regulation of skeletal growth and maturation in male mice. PNAS 97 5474-5479.

Walker KV \& Kember NF 1972 Cell kinetics of growth cartilage in the rat tibia. I. Measurements in young male rats. Cell Tissue Kinetics 5 401-408.

Weise M, De-Levy S, Barnes KM, Gafni RI, Abad V \& Baron J 2001 Effects of estrogen on growth plate senescence and epiphyseal fusion. PNAS 98 6871-6876.

Weissberger AJ \& Ho KKY 1993 Activation of the somatotropic axis by testosterone in adult males: evidence for the role of aromatization. Journal of Clinical Endocrinology and Metabolism 76 1407-1412.

Wickman S, Sipila I, Ankarberg-Lindgren C, Norjavaara E \& Dunkel L 2001 A specific aromatase inhibitor and potential increase in adult height in boys with delayed puberty: a randomized controlled trial. Lancet 357 1743-1748.

Received 8 March 2004

Accepted 15 April 2004

Accepted preprint made available 15 April 2004 